\title{
Subjective study on potts spine with therapeutic yoga intervention
}

\author{
Amudha Rani Narayanan
}

Yoga Therapist, Krishnamacharya Ashtanga Viniyoga, Chandigarh

\section{KEY WORDS}

Pott's Spine

Diabetes

Integrative Mind-Body Approach

Pain

Yoga

\section{*Corresponding Author:}

Amudha Rani Narayanan

Krishnamacharya Ashtanga Viniyoga

Chandigarh

Contact no: +91-9444118220

E-mail: namudha@hotmail.com

\begin{abstract}
This is a qualitative single subject intervention assessment involving the treatment of a 58 year old man, diagnosed with para-vertebral abscess due to tubercular pott's spine with Diabetes since 2008, administered with neuro anaesthesia for pain management, which could not succeed in providing complete relief and hence a parallel attempt was made to treat the same through an integrative mind-body approach to resolving pain. Basic challenges in this process were to conceptualize a personalized approach based on the constitution and personality of the seeker and selection of specific tools of yoga therapy to suit the individual's requirement. Adoption of yoga therapy involving synergized techniques resulted in holistic cure in a significantly reduced time interval. However, more studies are required to be adopted in the same manner to strengthen the line of the efficacy of such therapies in similar cases.
\end{abstract}

doi: 10.38205/imcr.010232

\section{Introduction}

This is a qualitative study on a patient affected with Tuberculosis (TB) of the cervical spine with an abscess in c6-c7. This paper analyses how soft process variables, like individual's personality, motivation, attitude, beliefs and nature (guna) plays a major role in enhancing the effect of yoga therapy (1).

Modern scientific methodology intends to establish facts or evidence by using objective methods, statistical models to infer the results. However, these tools themselves are based on a certain hypothesis. Such a measurement tool may be different from what yoga addresses. Yoga is not just a mechanical process of physical practices alone. It encompasses various other practices, wherein each practice contributes singularly as well as synergistically to the changes at the body-mind - intellectual levels. Sometimes the changes that occur in other dimensions may spark the mind, wherein the mind acts as a median and fastens the healing process subtly. These subtle changes should be captured and recorded by the therapist and researcher for documentation. Thus, personal, individual, tailor-made interventions with single-subject designs, involving repeated assessments and changes can study the long-term impact of yoga therapy (2). Adherence, diet, behaviour, daily activities, mood, and lifestyle practices are some of the outcomes that can be documented using single-case designs. This is a study on the effectiveness of yoga therapy on an intra-individual using a single case design. In this case study, the above said concepts have been attempted and the efficacy of the same was evaluated based on the clinical outcome.

\section{Prognosis of the disease}

Pott's disease, also known as tuberculous spondylitis, is a classic presentation of extra pulmonary TB. It most commonly involves the thoracic and lumbosacral spine. It is associated with significant morbidity and can lead to severe functional impairment. Progressive bone destruction leads to vertebral collapse and kyphosis. The spinal canal can be narrowed by abscesses, granulation tissue, or direct dural invasion, leading to spinal cord compression and neurologic deficits. Pott disease is the most dangerous form of musculoskeletal TB because it can cause bone destruction, deformity, and paraplegia (3).

\section{Case presentation}

The patient was a 58 years old male Banker. He had TB of the cervical spine (Pott's spine) in 2004 and he was put on ATT for 1.5 years daily regime. He was responding well to the medicines. He was put on a hard collar for 4 months and he was on oral medication for diabetic.

In 2018 he developed loss of weight and pain in the shoulder when he visited a Multi-Speciality Hospital, Gurugram, for shoulder impingement syndrome (MRI shoulder). MRI cervical spine was done before going for surgery. Paravertebral abscess Cervical Spine was detected with high sugar level and ketone. He was put on Insulin and operated on shoulder for a tissue tear in shoulders (03/06/2018).

Discharged on ATT for TB Cervical Spine (C6-C7, POTT'S spine). Patient developed severe intractable pain after reaching Chandigarh. He was admitted to Multi-speciality hospital for severe Neuralgic pain under Neurosurgery Department on $25^{\text {th }}$ June 2018 with major complaints of shoulder pain, neck 
pain and numbness in fingertips. Before admission to hospital, he was given $1 / 2$ Paracetamol drip at home to relieve pain, along with other oral NSAIDS, but got no relief (Table 1).

Table 1: Details of Medicine prescribed by doctor

\begin{tabular}{|c|c|c|c|}
\hline $\begin{array}{l}\text { S. } \\
\text { No. }\end{array}$ & 23 July 2018 & 04 Sept 2018 & $\begin{array}{l}\text { After yoga } \\
\text { intervention }\end{array}$ \\
\hline 1. & $\begin{array}{l}\text { C. Rifampicin } \\
150 \mathrm{MG}\end{array}$ & $\begin{array}{l}\text { C. Rifampicin } \\
600 \mathrm{MG}\end{array}$ & Rifampicin $150 \mathrm{mg}$ \\
\hline 2. & ---- & T. INH 300 & Isoniazid $75 \mathrm{mg}$ \\
\hline 3. & T. Levoflox $750 \mathrm{mg}$ & T. Levoflox $750 \mathrm{mg}$ & Stopped \\
\hline 4. & $\begin{array}{l}\text { Ethambutol } \\
1200 \mathrm{mg}\end{array}$ & Ethambutol $1200 \mathrm{mg}$ & $\begin{array}{l}\text { Ethambutol hydro- } \\
\text { chloride } 275 \mathrm{mg}\end{array}$ \\
\hline 5. & Streptomycin $1 \mathrm{G} \mathrm{IM}$ & Stopped & Stopped \\
\hline 6. & T. Telma 80 mg & T. Telma $40 \mathrm{mg}$ & Telmisartan $40 \mathrm{mg}$ \\
\hline 7. & T. Pyridoxine $20 \mathrm{mg}$ & T. Pyridoxine $20 \mathrm{mg}$ & Pyridoxine $20 \mathrm{mg}$ \\
\hline 8. & T. Pregalin 75 mg & T. Pregalin $75 \mathrm{mg}$ & Stopped \\
\hline 9. & ---- & T. Shelcal $500 \mathrm{mg}$ & Stopped \\
\hline 10. & T. Trajenta 5 mg & T. Trajenta $5 \mathrm{mg}$ & Stopped \\
\hline 11. & Inj. Lantus $25 \mathrm{U}$ & Inj. Lantus $25 \mathrm{U}$ & Stopped \\
\hline 12. & $\begin{array}{l}\text { Inj. Lorazepam - } \\
1 \mathrm{mg}-2 \mathrm{mg}\end{array}$ & Inj. Lorazepam & Stopped \\
\hline 13. & $\begin{array}{l}\text { Inj. Novarapid } \\
19 \text { U-BBF } \\
10 \text { U-BLN } \\
10 \text { U-BDN }\end{array}$ & $\begin{array}{l}\text { Inj. Novarapid } \\
18 \text { U-BBF } \\
10 \text { U-BLN } \\
10 \text { U-BDN }\end{array}$ & Stopped \\
\hline 14. & ----- & Vitamin D3 Sachet & ---- \\
\hline 15. & Emset $4 \mathrm{mg}$ & Stopped & Stopped \\
\hline 16. & Rantac $150 \mathrm{mg}$ & Stopped & Stopped \\
\hline 17. & Mucinac $600 \mathrm{mg}$ & Stopped & Stopped \\
\hline 18. & PCM 500 mg & ----- & Stopped \\
\hline 19. & $\begin{array}{l}\text { Buprenorphine Patch } \\
20 \text { Nicro/Week }\end{array}$ & ---- & Stopped \\
\hline 20. & ---- & ----- & Neurokind \\
\hline 21. & ---- & ------ & Febutaz $40 \mathrm{mg}$ \\
\hline
\end{tabular}

The patient continued $1 / 2$ paracetamol drip every 6 hours and received only mild relief. He was also administered ATT with decreased DOT regime. Subsequently, the pain became stabbing and burning like, for which Neuroanaesthesia consultation was done. Fentanyl patches, Buprenorphine patches were applied with very mild relief. But the pain persisted, and he was administered (oral) with Dolonex DT, Tab Dolo $650 \mathrm{mg}$, Pregalin, Tab Amitriptyline. The patient also developed deranged LFT and he was administered with Acetylcysteine as paracetamol toxicity was suspected.

Fever occurred on and off and the conditions persisted for a few months. The pain continued despite the use of ATT/ patches for more than 2 months and ultimately, he was again admitted as in patient for pain on $13^{\text {th }}$ August 2018. He was also given oral Narcogin forte (Paracetamol + Codeine) (Table 1)

\section{HEYAM - Identifying the problems or symptoms}

The patient's wife, a medical practitioner, approached the Krishnamacharya Ashtanga Viniyoga school during the first week of August 2018, seeking therapeutic yoga intervention for pain management alone. The author, a Yoga Therapist by profession, made a home visit and observed that the patient was in severe pain and was not in a stage to speak, but to the content of the therapist, the patient was diagnosed with the disease (vyaadi) only at his physical level - physiological level. It was observed and referred that the disease had not percolated to the psychological level and constitution of his Gunas were positive for therapeutic intervention at that condition.

In this juncture, it is pertinent to reiterate that Yoga examines individuals in terms of their mental/spiritual level according to the three Gunas. The three Gunas - Sattva, Rajas and Tamas - also promote different kinds of temperament based on the dominance of one or the other Gunas (4).

The patient was anxious to get out of the pain and was eager to get back to his normal life. This was a positive sign for the therapists, as people who are sceptical and doubtful are slow healers and the lack of compliance may aggravate the situation further. Therefore, it is advisable to not to apply the principle universally in all cases and better to wait and intervene only at the appropriate moment.

In this specific case, since the patient's psycho-somatic level was found to be positive and healthy, the counselling was started. The patient broke down with the pain and was questioning his own existence with such severe pain. He was counselled with an authority to separate his pain and observe it without causing any suffering to the mind and advised to strengthen his body with the will of his mind.

During the subsequent visit, he was trained with few spiritual conscious movements called nyasam with mental chanting. Since the patient was a non- believer, the therapist did the chanting for him. Though a lot of positive changes were seen in the patient, after a few days patient was hospitalised in the multi-speciality hospital, Neurology department, with the onset of acute pain and was discharged on $16^{\text {th }}$ August 2018. Therapy was continued in the ward.

After his discharge, he resumed yoga therapy with good adherence. He expressed, he felt strong within, when he did manasic chanting with co-ordinated breathing in the ward. $\mathrm{He}$ felt relieved after every practice. Subtle changes were noted at his spiritual level. It was a positive sign for the therapists to go ahead with their protocol.

\section{HETU - Understanding the causes of symptoms}

\section{Dietary changes}

When the naadi of the patient was examined on the first day, there was plenty of disturbance in vaata element observed and therefore strict dietary changes were advised. The patient was advised to have only semi-liquid double-boiled food. 
All pulses except split green gram were prohibited. He was advised to take clear mutton soup for dinner to fight disease in the spine. Light and easy to digest food was advised. With these changes, the patient felt that much of his shooting pain started disappearing.

\section{HANAM - Establishing goals}

Table 2: Establishing Goals

\begin{tabular}{|c|c|c|c|}
\hline S. No. & Goal & Duration & Result \\
\hline 1. & $\begin{array}{l}\text { Relief from pain and } \\
\text { relaxation }\end{array}$ & $\geq 2$ weeks & Yes \\
\hline 2. & $\begin{array}{l}\text { Improve sensation in } \\
\text { fingertips }\end{array}$ & $\geq 6$ weeks & Yes \\
\hline 3. & $\begin{array}{l}\text { Improve range of movement } \\
\text { and functionality in arms }\end{array}$ & $\leq 10$ weeks & Yes \\
\hline 4. & $\begin{array}{l}\text { Reducing shoulder blade } \\
\text { pain, related to tissue tear }\end{array}$ & $\leq 10$ weeks & Yes \\
\hline 5. & $\begin{array}{l}\text { Strengthening exercise and } \\
\text { stretches }\end{array}$ & $\begin{array}{l}\text { From } 6^{\text {th }} \text { week } \\
\text { till now }\end{array}$ & Yes \\
\hline 6. & $\begin{array}{l}\text { Improving spine flexibility } \\
\text { and strengthening core } \\
\text { muscles }\end{array}$ & $\begin{array}{l}\text { From } 6^{\text {th }} \text { week } \\
\text { till now }\end{array}$ & Yes \\
\hline 7. & $\begin{array}{l}\text { Improving the mobility in } \\
\text { knees }\end{array}$ & & $\begin{array}{l}\text { Yet to } \\
\text { achieve }\end{array}$ \\
\hline 8. & Controlling diabetes & & On Process \\
\hline 9. & $\begin{array}{l}\text { Developing inclination } \\
\text { towards yogic philosophy } \\
\text { and spirituality }\end{array}$ & & Yes \\
\hline
\end{tabular}

\section{UPAYAM- Using the tools in yoga therapy}

Yoga Therapy: The first-week therapy sessions were focused on breathing and consciousness on fingertips, also counselled to alienate the pain physically and to consciously observe the pain. Seeker observed that his entire body was in pain, he could not localise the pain. He was unable to focus on breathing much, he was advised with Yoga Nidra, and he was not able to relax during Yoga Nidra completely due to acute pain. Ayur mantra chanting was done by yoga therapist for him.

Integration with allopathy: Patients therapy sessions were placed after the pain killers were administered for effective Yoga Nidra sessions. Slowly, breathing was introduced including inhalation through nose and exhalation through the mouth, nyasam techniques in fingers with manasic chant (Figure 1). Since his right hand was affected, simpler movements of finger and wrist along with breathing were given in left hand and virtual movement with breathing in the right hand. Yoga Nidra with music was also given and every practice session lasted for 12-15 minutes and such sessions were repeated several times in a day.

Subtle changes happened at his psycho-somatic level. Subjective analysis - changes at his spiritual level were noted.

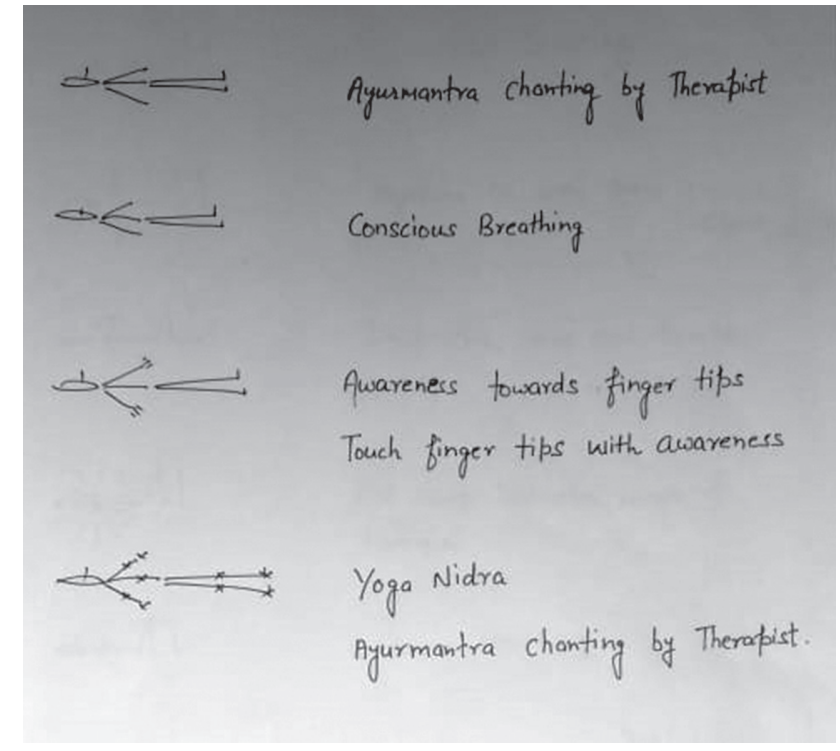

Fig. 1: Aasna sheet for the first week

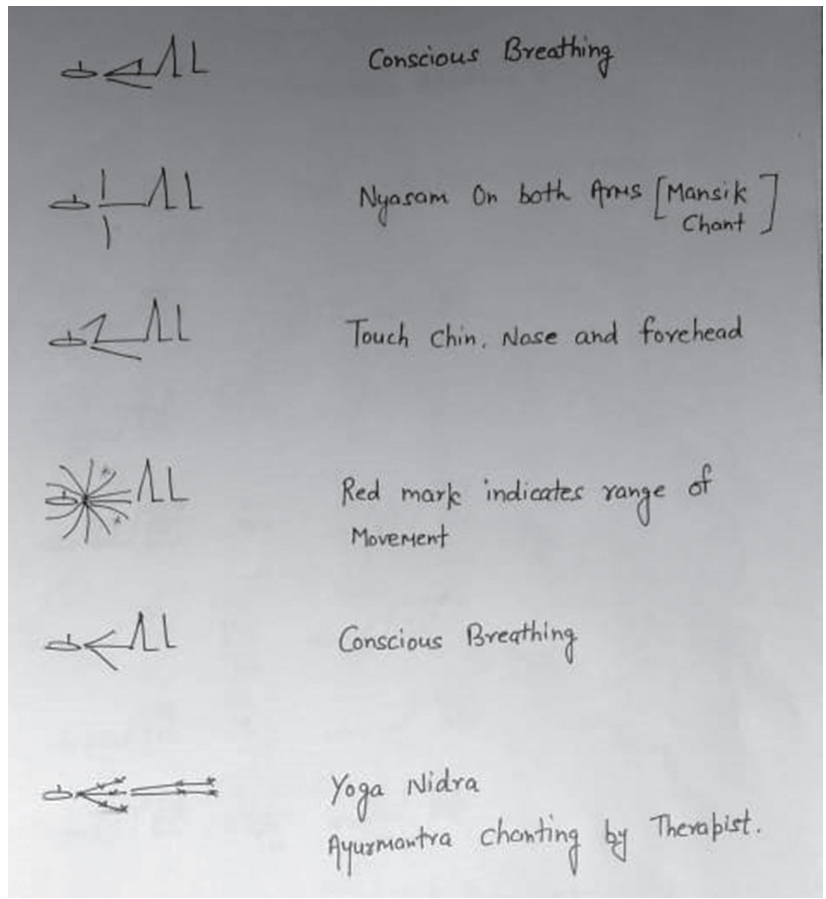

Fig. 2: Aasna sheet for the second week

On the Second week - Touch chin, nose and forehead withco-ordinated breathing and chanting were introduced. While in right hand virtual movements of the same was administered. Seeker was able to relax during Yoga Nidra sessions. Short Nidra after the therapy sessions helped the seeker in pain management (Figure 2).

All the asanas were modified to suit the mood and capacity of the patient then and there. For two weeks, his head and neck were kept stable and movements were given only to 
arms, wrist and fingers. His lower limbs and back were kept completely stable. Seeker started showing a lot of improvement in the range of movements in his upper arms and the pain got localized to his cervical and shoulders.

\section{Third and fourth week}

Legs were kept elevated for third week practice also, small movements co-ordinated with breath were introduced to legs without disturbing his back. Thoracic breathing with ratio was introduced. The ratio of breathing was changed from practice to practice based on the mood and pain level (Figure 3).

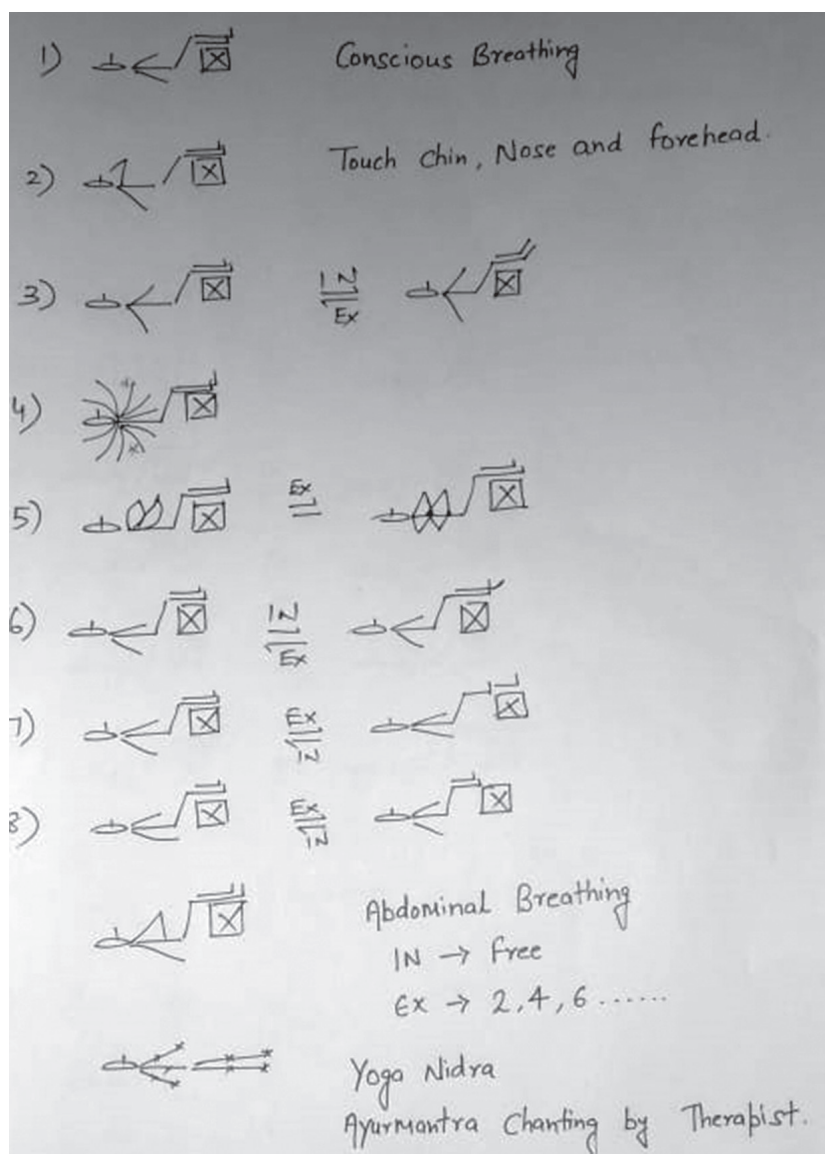

Fig. 3: Aasna sheet for the third week

During the fourth week, the cervical exercises in seated postures were introduced. Pain killers were largely reduced, and therapy was given in seated posture with a supported back and without any independent movement of the neck (Figure 4.1, 4.2).

\section{Fifth week}

Patient started showing steady improvement and he was introduced with the task of short strolls and Chandra bhedana Pranayama. Further, the range of movement in the right arm was gradually increased. Standing asanas with wall support

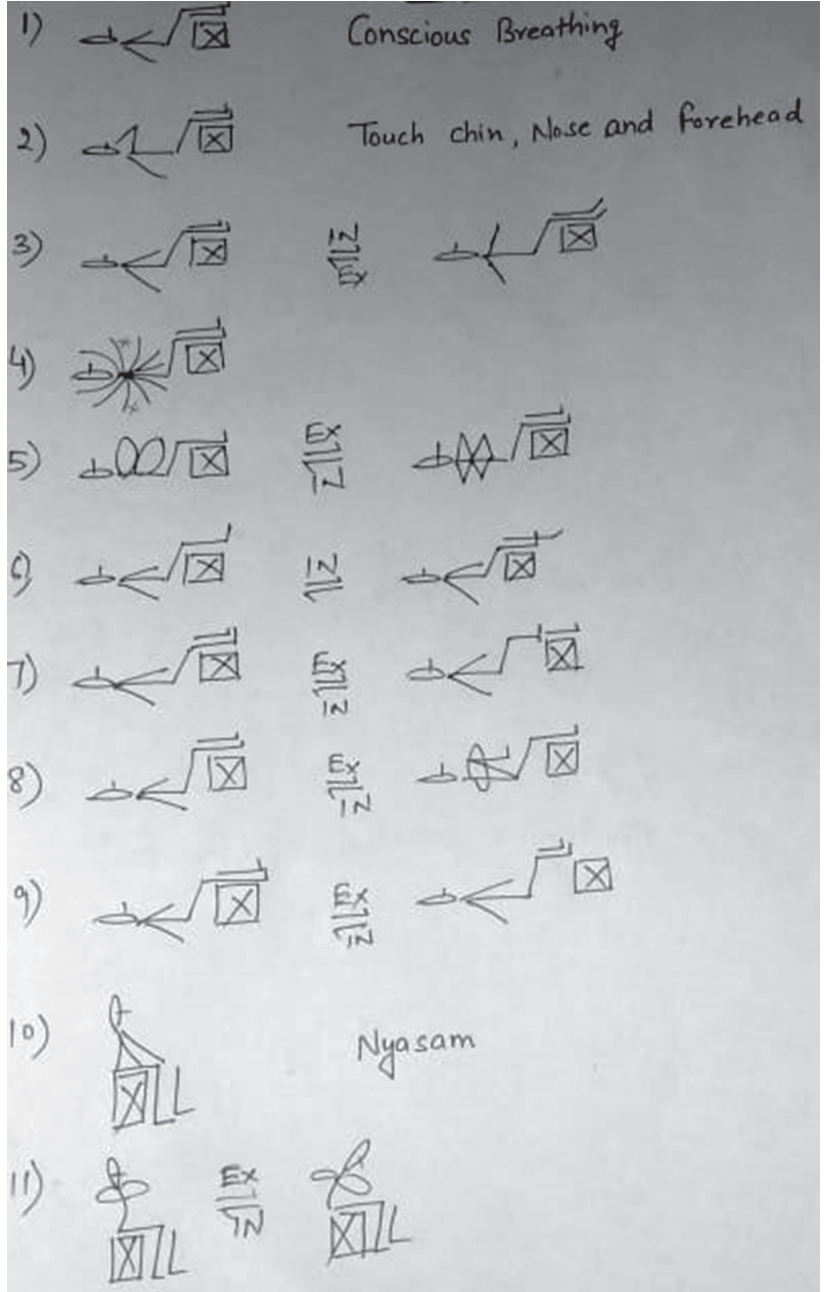

Fig. 4.1: Aasna sheet for the fourth week - page 1

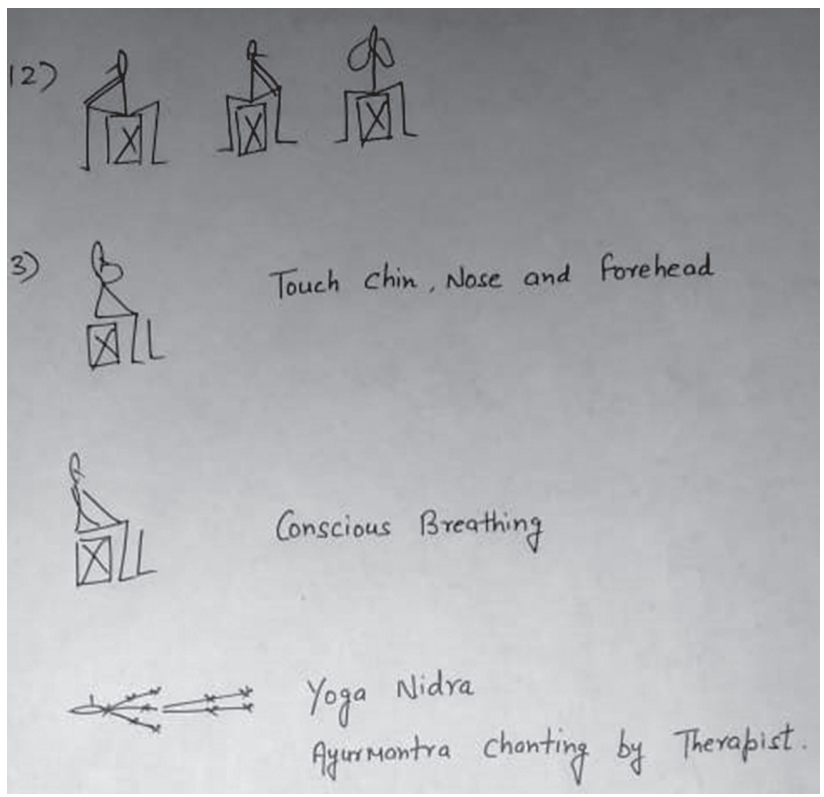

Fig. 4.2: Aasna sheet for the fourth week - page 2 
were introduced. Seeker became independent, practised yoga therapy several times in a day and followed the dietary changes regimentally.

\section{Sixth - Eighth week}

Seeker returned to his routine and joined his office within 8 weeks of the therapeutic session. Strengthening exercises were started for the core muscles which were continued for 12 weeks. He increased walking distance to $1-2 \mathrm{~km}$. Resumed all his regular work (Figure 5).

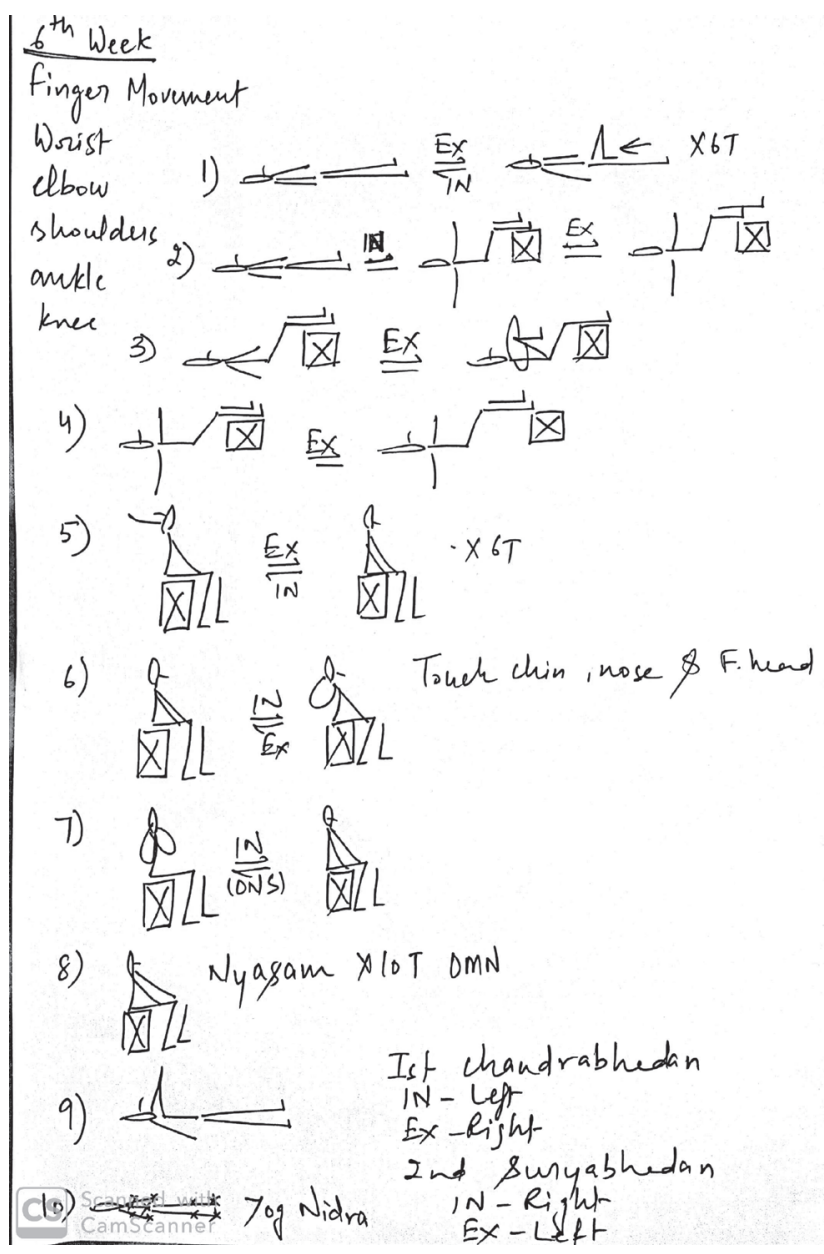

Fig. 5: Aasna sheet for the sixth week

\section{Ninth week -Twelfth week onward}

All his medicines except ATT and Diabetic tablets were stopped. Separate practices for the evening were introduced to improve his quality of sleep. Seeker felt more energetic and stronger. Slowly strengthening exercises were introduced, lots of back arches with inhale hold was given to increase his immunity (Figure 6). He resumed his photography, his regular travels and inconsistency in practice with negligence toward health, brought the shoulders pain back. The fluid collection was found (MRI shoulders). Seeker resorted to yoga therapy

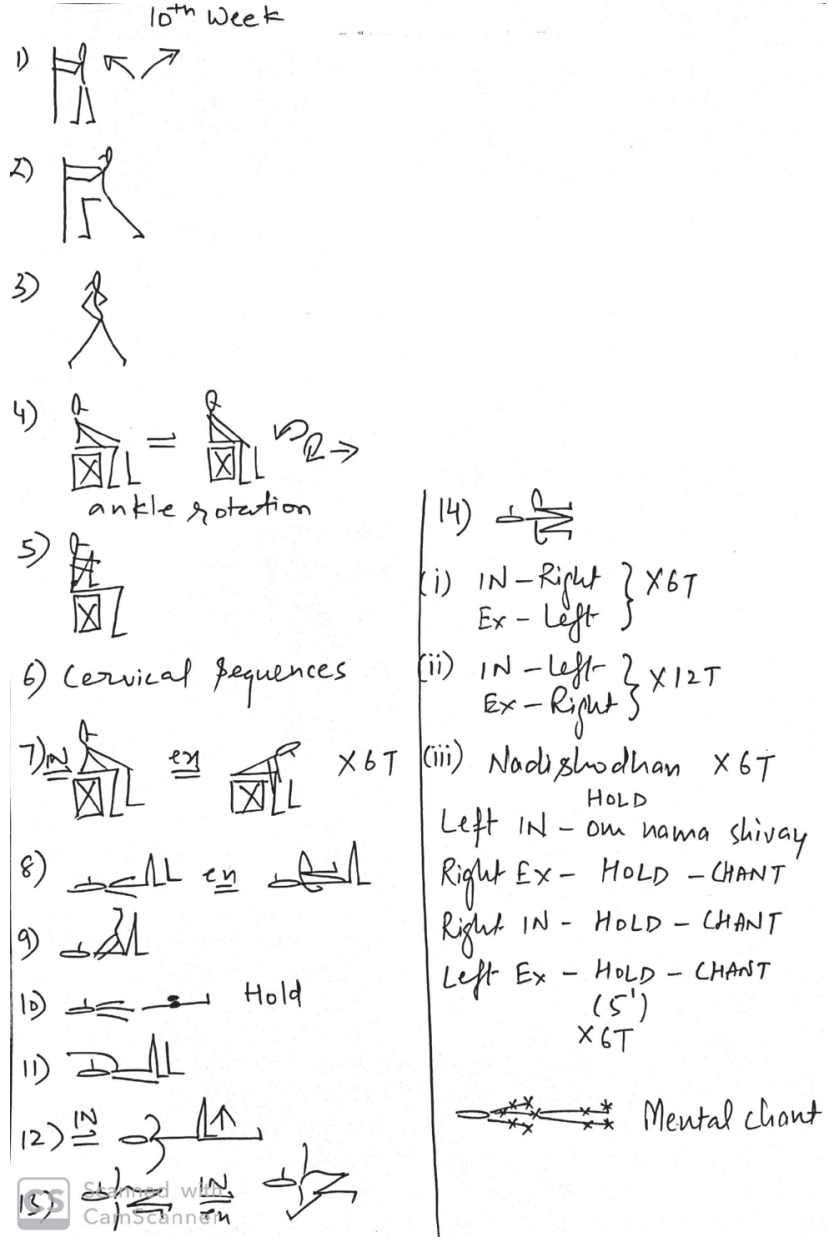

Fig. 6: Aasna sheet from ninth week onward

for avoiding surgery; the situation reverted within two weeks with therapeutic intervention. Yoga therapy expedites the healing process in students who are already practitioners.

Presently, more focus is being kept on controlling his Diabetes with short chanting and strong practices repeated 2-3 times a day. He is getting more inclined towards yogic philosophy, also his belief and trust towards therapeutic yoga have become irrevocable. The entire treatment protocol for 12 weeks is listed on Table 3.

\section{Discussion}

This study convincingly proves that individualised and personalized therapeutic approaches bring in holistic heal in notably reduced time. Chronic ailment and acute pain of the patient was healed within a brief period of time with the mind-body intervention.

Family members of the patient resorted to yoga therapy after a long ordeal, though ATT and other medications were administered, the patient was hospitalised on and off with unbearable pain for a few months. He was diagnosed with anxiety and depression, medications were administered for the same too. 
Table 3: Treatment chart

\begin{tabular}{|c|c|c|c|}
\hline \multicolumn{2}{|c|}{$1^{\text {st }}$ Week (refer Figure 1 ) } & Duration of session & Result \\
\hline 1. & Ayur Mantra Chanting by Therapist. & \multirow{4}{*}{$\begin{array}{l}12-15 \text { minutes at a time } \\
\text { which was repeated } \\
\text { several times a day. }\end{array}$} & \multirow{4}{*}{$\begin{array}{l}\text { Subtle changes } \\
\text { happened at his } \\
\text { psycho - somatic level }\end{array}$} \\
\hline 2. & Conscious breathing. & & \\
\hline 3. & Consciousness on Finger tips. & & \\
\hline 4. & Yoga Nidra/Ayur Mantra Chanting by Therapist. & & \\
\hline \multicolumn{4}{|c|}{$2^{\text {nd }}$ Week (refer Figure 2) } \\
\hline 1. & Conscious breathing & \multirow{4}{*}{$\begin{array}{l}\text { For } 2 \text { weeks focus was } \\
\text { on movement of arms, } \\
\text { wrist and fingers and } \\
\text { Head and neck kept } \\
\text { stable. }\end{array}$} & \multirow{4}{*}{$\begin{array}{l}\text { Improvement in range } \\
\text { of movement in his } \\
\text { upper arms and pain got } \\
\text { localized in cervical and } \\
\text { shoulder }\end{array}$} \\
\hline 2. & $\begin{array}{l}\text { Touch chin, Nose, Forehead given with movement for left hand and Virtual } \\
\text { movements given for right hand. }\end{array}$ & & \\
\hline 3. & Range of movement of left arm was 30 degree and right arm was 10 degree. & & \\
\hline 4. & Yoga Nidra/Ayur Mantra Chanting by Therapist. & & \\
\hline \multicolumn{4}{|c|}{$3^{\text {rd }}$ Week (refer Figure 3) } \\
\hline 1. & Conscious breathing & \multirow[t]{5}{*}{1 hour, thrice a day } & \multirow[t]{5}{*}{ Pain killers reduced. } \\
\hline 2. & $\begin{array}{l}\text { Range of movement of left arm was } 40 \text { degree and right arm was } 15 \text { degree } \\
\text { in exercise no. } 4 .\end{array}$ & & \\
\hline 3. & Keeping Legs elevated, feet movement in co-ordinating with breathing given. & & \\
\hline 4. & Thoracic breathing with ratio introduced. & & \\
\hline 5. & Yoga Nidra/Ayur Mantra Chanting by Therapist. & & \\
\hline \multicolumn{4}{|c|}{$4^{\text {th }}$ Week (refer Figure $4.1 \& 4.2$ ) } \\
\hline 1. & Conscious breathing. & \multirow[t]{5}{*}{1 hour, thrice a day } & \multirow{5}{*}{$\begin{array}{l}\text { Therapy given in seated } \\
\text { posture, supporting } \\
\text { back without neck } \\
\text { movement. }\end{array}$} \\
\hline 2. & $\begin{array}{l}\text { Range of movement of left arm was } 60 \text { degree and right arm was } 30 \text { degree } \\
\text { in exercise no. } 4 .\end{array}$ & & \\
\hline 3. & $\begin{array}{l}\text { Cervical exercises in seated postures were introduced with reduced range of } \\
\text { right arm movement. }\end{array}$ & & \\
\hline 4. & Sitali Pranayam on all 3 sides introducesd. & & \\
\hline 5. & Yoga Nidra/Ayur Mantra Chanting by Therapist. & & \\
\hline \multicolumn{4}{|c|}{$5^{\text {th }}$ Week } \\
\hline 1. & Given task of short strolls. & \multirow[t]{4}{*}{1 hour, thrice a day } & \multirow{4}{*}{$\begin{array}{l}\text { Range of movement in } \\
\text { right arm increased }\end{array}$} \\
\hline 2. & Chandra bhedana Pranayama introduced. & & \\
\hline 3. & Standing asanas with wall support were introduced. & & \\
\hline 4. & Dietary changes introduced. & & \\
\hline \multicolumn{4}{|c|}{$6^{\text {th }}-8^{\text {th }}$ Week (refer Figure 5) } \\
\hline 1. & Strengthening exercises given for core muscles. & \multirow[t]{2}{*}{1 hour, thrice a day } & \multirow{2}{*}{$\begin{array}{l}\text { Joined office and } \\
\text { resumed regular work. }\end{array}$} \\
\hline 2. & Started walking 1-2 kms. & & \\
\hline \multicolumn{4}{|c|}{$9^{\text {th }}-12^{\text {th }}$ Week (refer Figure 6) } \\
\hline 1. & Strengthening exercises given for core muscles. & \multirow[t]{3}{*}{1 hour, thrice a day } & \multirow{3}{*}{$\begin{array}{l}\text { All medicine except } \\
\text { ATT and diabetes were } \\
\text { stopped }\end{array}$} \\
\hline 2. & Lots of back arches with Inhale hold given to increase immunity. & & \\
\hline 3. & Evening exercises added to improve quality of sleep. & & \\
\hline
\end{tabular}

On the first visit, we found the physical body of the seeker in a decrepit state, there was no hope of starting the therapy with any physical movement or with the breath, so therapy was initiated from intelligence- mind- breath- body level. Seeker came out of the pain and was back to normal life within 8 weeks.

Subtle changes at intellectual- mental level could have kindled self-healing. Along with allopathic medications,
Intermittent Counselling sessions, dietary changes, lifestyle management, proper physical and breathing exercises, chanting, japa and mudras synergistically got his health back.

However, many such studies need to be done in a longitudinal design in order to evaluate how yoga therapy can be made effective on different personalities based on their inherent qualities of nature. 


\section{Conclusion}

In this case study, personality and constitution of the person favoured yoga intervention and was treated in a remarkably short duration. However, the same therapeutic intervention may or may not favour other personalities. Though yoga therapy has a solution for all diseases and illness, therapeutic tools, methods and period of intervention and healing will differ from individual to individual.

Here, the person's illness was caused by the disease he contracted lately. Sometimes diseases which come from outside - adi bautika, are much easier to cure, even if it has severely affected the body physically and physiologically. Diseases that are carried from birth or diseases originating at a mental level are much difficult to cure holistically.

Holistic wellbeing of a human is always linked to his body-mind - intelligence-spiritual link. Yoga philosophy intends to enhance his wellbeing at all levels. It helps a person live harmoniously and peacefully within and establish the same link with the outer world also.

\section{Acknowledgement}

The author acknowledges thanks to her team of therapists: Karanveer, Mandeep, Jyothi Tariyal and Gurpreet for their relentless optimism and hard work. Thanks to Dr Jagriti for her co-operation and initiative.

\section{Authorship contribution}

It was a single subjective intervention, solely with the author (Amudha Rani Narayanan).
The author consents to get the study published in IMCR and declares that the contents are original and no fact has been hidden or manipulated to best of her knowledge (or in any standard format, as provided by the journal).

\section{Source of funding}

The study is a single subjective intervention done with the patient who availed treatment with no external funding.

\section{Informed consent}

Yes.

\section{Conflict of interest}

None. It is only a supplementary methodology attempted without inhibiting any existing theory/practices.

Received Date: 14-02-20; Revised Date: 19-05-20

Accepted Date: 02-06-20

\section{References}

1. Shilpa S and C G Venkatesa Murthy: Understanding Personality from Ayurvedic perspective for psychological assessment: A case. Ayu 2011;32(1):12-19.

2. Dwarakanath D and V Duraiswami: Studying Efficacy of yoga therapy: Individual centric approach. International Journal of Academic Research and Development 2016;9(1):73-76.

3. Jose A Hidalgo: Pott Disease (Tuberculous Spondylitis). https://emedicine.medscape.com/article/226141-overview. 2019.

4. Khanna P, Singh K, Singla S, Verma V.: Relationship between Trigula theory and well-being indicator. Int J Yoga Philos Psychol Parapsychol 2013;1:69-74. 